\title{
Indigenous Storytelling in the Contemporary World: An Interview with Drew Hayden Taylor
}

Rubelise da Cunha ${ }^{1}$

Submetido em 25 e aprovado em 29 de agosto de 2018.

August 9, 2018

Indigenous writers celebrate the resistance and survival of traditional storytelling in contemporary literature, and Ojibway writer Drew Hayden Taylor has done his part in Canada. He is an award-winning playwright who has spread the knowledge of Ojibway storytelling he gained growing up on the Curve Lake First Nation, located in Peterborough (Ontario), where he still has a home and kindly received me there. Taylor has published thirty books which include plays, novels and short stories, and is also well-known as a journalist and filmmaker, with documentaries such as Red Skins, Tricksters and Puppy Stew (2000) on Native humor, and Searching for Winnetou (2018), which opened the Asinabka Festival in Ottawa this year.

One of the themes that Drew Hayden Taylor explores in his writings is identity. In a very humorous way, he uses his experience of growing up in an Indigenous community as a blond and blue-eyed Ojibway to question stereotypes associated with Indigenous people. The experience of moving from Curve Lake to the city of Toronto also gave him a critical perspective about stereotypes associated with Indigenous people and the complexities of Indigenous experience on the reserve and in city life, as we observe in his book Funny, You Don't Look Like One: Observations of a Blue-Eyed Ojibway (1996).

In his career as a writer and storyteller, Drew Hayden Taylor contributes to social and critical awareness of Indigenous experience and the legacy of colonialism, in a way that it promotes cross-cultural dialogue and makes us reflect about ongoing colonial 
practices against Indigenous people in Brazil. In a very pleasant afternoon during the Asinabka Festival in Ottawa, we had a conversation about his life and career, traditional and contemporary Indigenous storytelling, and on how literature and humor celebrate the continuance of Indigenous traditions.

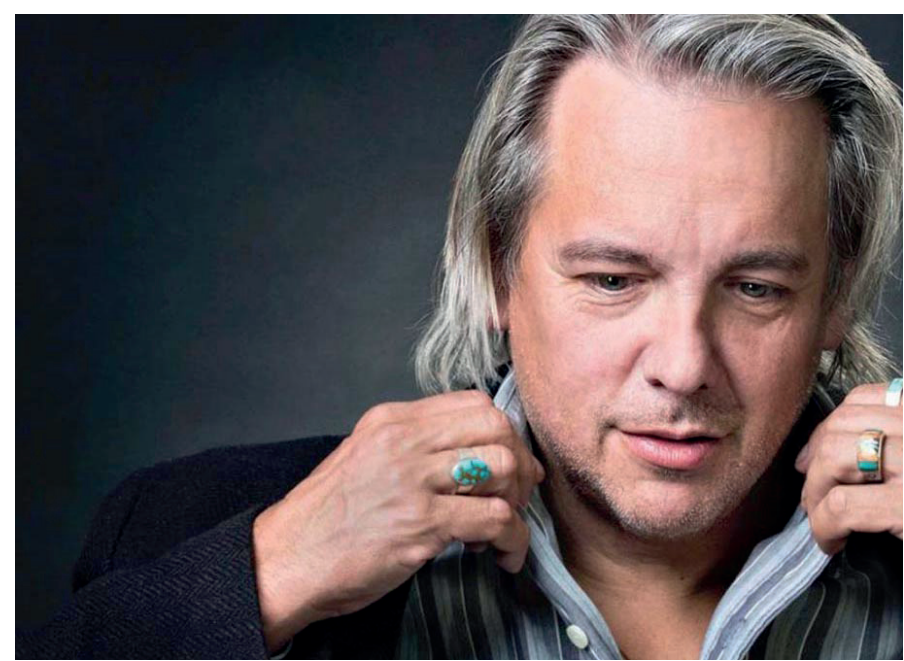

RC: In your lectures and interviews, you introduce yourself as a "contemporary storyteller". In what ways do you think the contemporary storyteller is similar to or different from the traditional storyteller?

DHT: It all comes down to telling a story, a story has a beginning, a middle and an end. When I say I am a contemporary storyteller that basically means we've gone from telling stories around the campfire, around the kitchen table, to telling stories on the stage, the page and the screen. So in my journey as a contemporary storyteller I've been telling my stories on the stage, in novels, television shows, movies, in whatever form that occurs to me, and in whatever genre too, science fiction, etc. So about the fact that I consider myself a contemporary storyteller, it is just finding and exploring and celebrating different ways to tell stories that come from the Indigenous spirit. 


\section{$R C$ : So do you think it connects with traditional storytelling?}

DHT: I think so too. I had a conversation once with a traditional storyteller just out of Manitoulin Island, in a place called Birch Island. She told me that "we need new stories as much as we need the old stories", and I took that to heart, and that's very important. So when I sit down to write, I try to tell stories that still have Anishinaabe roots, the Anishinaabe DNA all through it. What I've just done is find new ways to tell that story. So what may have been a hundred years ago a traditional story told during the winter time in Native communities, now is a story told on the various media that at its heart and its soul, and its essence, I think still have Anishinaabe presence to it, and that is very important to me. Now that's not to say I'm against telling stories that aren't Native oriented. One of the questions I get asked frequently is "Are your writing something that is not Native? Do all your stories have Native characters?" and at this point, yes, they do. If you look back to Western civilization they've written stories in one form or another for like three or four thousand years, and we've been basically telling our stories in Western written form for maybe forty, fifty, sixty years, so there is a lot of catching up to do and I'm doing my bit to catch up telling these stories. Now at some point, yes, all people, all cultures, all nations in whatever form of development have at the beginning a storytelling origin and I understand that, I recognize that and I celebrate it. So, at some point, I will tell stories that may not have Native content. The best example I like using is my dream someday, in my bucket list, is to write something Star Trek, and I'd love to write an episode or something to do with it, somewhere down the line. It may or may not have some Native presence in it, but it is not essential, but that would be my dream. So I do think it is possible as a First Nations writer to write a non-First Nations story.

RC: You started your career in theatre, but have also written texts in many different genres, such as novels, short stories, essays, television scripts. Can you tell us about your creative process, and in what ways you felt it was necessary to express yourself in many different genres?

DHT: Actually, I didn't start in theatre. Theatre was my second career. My very first two or three serious writing credits were television. When I was twenty five I wrote an episode 
to a Canadian show called The Beachcombers. When I was twenty seven, I got involved in theatre. Tomson Highway asked me to be the writer in residence for Native Earth ${ }^{2}$ based on my television writing because he was kind of desperate, so I did, and that was when I got into theatre, so that was technically my second career. It was interesting that I started in television and then went into theatre. Usually it is the reverse, but for me it was that way. Primarily, because I grew up in an oral environment, an oral background. That is to say I learned to tell stories through how people talked, how people told stories, so I learned how people expressed themselves in different unique ways. Because of that, it gave me perspective on writing dialogue, on writing characters that expressed themselves through dialogue. So when I went to television having never taken a television writing course in my life, when I went to theatre having never taken a theatre course, I sort of instinctively knew how to create characters that expressed themselves through unique dialogue. One of the number one problems that first time writers have is frequently all characters sound alike, except for the name on the top of the dialogue, they all talk the same, and that is not the way real life is. One of the advantages my Aboriginal heritage gave me was the fact that I inheritably understood people talk differently and express themselves differently, so that is one of the reasons I think I became successful in television, in theatre, and then from them I went into writing non-fiction, articles and essays, and then I started writing novels, including a graphic novel. For me, and I've said this before, it all comes down to telling a good story, what is the best way to tell a story: is this story a novel? Is it a play? Is it a short story? Once I figure that out, if it is a play, what am I trying to say? Who am I going to say it through? And I've been in situations in which I wrote a play and it did not work, I put in on the shelf, and then ten years later I got the opportunity to write a novel and I took it off the shelf and it became The night wanderer. I had written it as a play, but it was meant to be a novel, but I wasn't ready to write a novel at that time, and then later I did and it was a successful novel. Part of the fun is figuring out what is the best way to tell a story, what is the best way to express this idea. Once I come up with that idea, I just plot it out, what is my beginning, my middle and my end, and then I sit down and do my best to create it. 
$R C$ : Your ideas on your process of writing remind me of Lee Maracle's arguments in her essay Oratory on Oratory, when she defends that the point of departure when analyzing Indigenous literature should be the concept of story and not Western literary genres.

DHT: Looking at traditional native storytelling in terms of theatre, theatre by definition, by description, by execution is Western European Greek method of storytelling, and Native people I think adopted it, it became the vehicle of choice in the late 1980s, early 1990s for Native people to tell oral story because it came through this oral storytelling in theatre, which is the logical progression of storytelling, so it was relatively easy. The more I've worked with it I began to notice similarities and differences between theatre and oral storytelling. For instance, in terms of Native storytelling being transferred into theatre, the two major differences that I find is one, the concept of conflict. In Western drama, drama comes from conflict, and conflict comes from characters. In Native storytelling there is a different perception of conflict, because when you live in small family groups, five to ten people, open overt conflict can be detrimental to the harmony of that family grouping, so there is a different way of processing the conflict, whereas in Western drama there are three types of conflict: person versus nature, person versus person, or person versus him/herself. In Native storytelling there are different ways of exploring that, it is not that overt. If you look at The Rez Sisters, it is the story of seven Native women who want to go to Toronto to participate in the world's largest bingo game, that's the plot. No major forms of conflict other than some squabbling because they are all sisters or halfsisters and they have to raise money to go. The plot is not progressed through Macbeth or through Death of a Salesman, through all these different things where you have this emotional cathartic ringing of characters bumping head to progress the story. It is a much more subtle, organic method of storytelling. In Someday, I remember when I was being produced somewhere, one of the artistic directors said, in his opinion, the information came a little too easily, he said it needed to be pulled and thought to be brought out, and I and the artistic director who had spent a lot of time in Native communities said that is not the Indigenous way, and so we kept it in. I say that keeping in mind there are exceptions to the rule. I am sure there are non-Native plays that have a more subtle way of dealing with conflict and there are Native plays that have a more overt way of dealing 
with conflict. The other interesting thing, in terms of Native theatre, is the concept of a central character. Who is the central character of Macbeth, Hamlet, King Lear, Death of a Salesman? In Western drama, Western literature, there is a central character who has an objective or a goal, and he spends the entire story overcoming a series of obstacles to either achieve or be denied their goal. That's what happens in the majority of theatre, novels, etc. In a lot of Native theatre there is no central character because the community is more important than the individual. For anybody to be more important than the group of people is often looked upon, and frowned upon. There is a pueblo that, during festivals, a character dresses up in a clown outfit whose function is to go out and ridicule people in the community who have put on an attitude or have become outrageous or more important or risen above the rest of the community, and their purpose is to shame them into being part. The best terminology is harmony within the community, and if anybody becomes more important than anybody else, that disturbs the harmony. So in the Rez Sisters, who is the main character? There isn't one. In Dry Lips, who is the main character? There isn't one. For me, it is a very important thing that the community is more important than the individual. And again, keeping in mind there are always exceptions to every rule.

$R C$ : Do you think this concern with harmony and balance has to do with your ideas in the article "Alive and Well: Native Theatre in Canada", where you mention that theatre is the logical extension of storytelling? So could we say that theatre is the genre that best translates or expresses traditional oral storytelling?

DHT: For fifteen years of my career as a successful writer I would write one short story a year for a while because I was very uncomfortable with the prose tradition. The written sentence in prose has to be exact and correct, whereas very few of us speak in perfect English; we speak in a colloquial manner. And as I stressed earlier, because I come from an oral culture, I can fake that, I can do that, but when writing prose that was very difficult for me to feel comfortable in. It was after fifteen years that I wrote a novel, very much worried about my knowledge of written English, and then I wrote two collections of short stories and two novels later. Writing non fictional essays and articles, I frequently write them from the first person singular. I'm much more comfortable doing that because it 
is still vernacular "me talking", "me lecturing", "me expressing an idea", and I've had editors who have helped me with that. As you were saying earlier, I do believe that theatre is the closest genre to traditional oral storytelling, and that's why there is gravitation early on from the late 1980 s to the early 1990 s when that was the vehicle of expression for most Native people.

$R C$ : There is this more holistic conception of traditional storytelling as a performance or a ceremony in which there is the construction of knowledge, and spiritual entities would be present and participate. Do you think that this sacred and spiritual dimension of Indigenous oral storytelling can be maintained in Indigenous theatre, and in Indigenous written literature in general?

DHT: I think so. It depends on the writer, on the story the writer wants to tell, and the atmosphere they want to create. It depends where you are, where you will find spiritualism too. If you are in a theatre in downtown Toronto, with primarily an audience of three hundred non-Native people, you don't know how much they are going to understand, how much they are going to appreciate, so that's a difficult question to answer, but I do think that it can be achieved and it can be explored. And there are so many talented Native playwrights out there and I think it has been expressed in a number of different levels.

$R C$ : In that same article, "Alive and Well: Native Theatre in Canada", you mention that theatre is a logical extension of the storytelling technique and that it "becomes a sort of cathartic release after so many years of being silenced" (1996, p. 30). Could you comment on that?

DHT: The idea that I got from that was a quote that Tomson Highway uses in the Introduction to the Rez Sisters. There is an amazing introduction in that play where he talks about many things and he says "Before the healing can take place, the poison must be exposed", and that is essentially true. If you talk to any psychiatrist, any therapist, if you have been hurt, if you have been damaged, if you have been abused, any of these things, half of the battle is admitting it, is facing it, and then from there the healing begins. In terms of theatre, you've got the theatre that dealt with residential schools, sexual abuse, the scoop-up, all these different things. I often refer to the fact that the vast majority of 
Native theatre consists of three themes: historical narratives, victim narratives, or the byproducts of post contact stress disorder. A lot of the plays that come from the Native community are dark, bleak, sad, and angry and that is primarily because they are dealing with the problems of contact and of colonialism, so writing about it, dealing with it, expressing it, and putting it up on the stage is definitely a healing mechanism, and I think it is a way of exorcizing those demons - this is what is wrong, I've got it out from me, and now I can begin healing.

$R C$ : I think your ideas relate very well with the opinion of Cherokee Two-Spirit writer, activist and performer Qwo-Li Driskill when he says that through the naming of the wounds healing can take place. He believes that through theatre oral traditions can be continued and new stories for a decolonized future can be imagined, since it provides the space for Indigenous people "to engage in the delicate work of suturing the wounds of history" (p. 155). In what ways do you think that your plays contribute to this healing? Does humor have a function in this healing process?

DHT: Yes, it does very much. Any group of Native people together anywhere they will start laughing quicker and twice as hard as any other group of people. Humor is very important to the First Nations culture. And that was made very obvious to me when I was talking with an elder from the Blood Reserve in Alberta who told me that in his opinion, for Native people, humor is the WD- $40^{3}$ of healing, meaning it promotes, it encourages and strengthens healing. And I have been in situations in which there had been real tragedies, conversations were real tragedies, and then we just add this snap of fingers, and we make a joke and everybody will laugh. So I certainly do, I always believe humor is healing in our culture, and that's one of the reasons I do what I do. Other writers are very good at showcasing and focusing upon the more negative aspects of First Nations community. I prefer to celebrate the more positive aspects in the Native community, the humor, the culture, all the other things. One of the best comments I ever got was at my play Crees in the Caribbean in Thunder Bay. This very well dressed contemporary Native woman who brought a group of people from her office to my play told the artistic director that she likes my plays more than the others because she can relate to them. She's is looking at the 
characters and she says: "That is my grandparents, and they laughed, and I'm laughing at this play, and I so relate to this. I understand the need for the darker stuff, but this one is closer to my heart than the sadder ones", and that kind of thing really helps me. Another time an old man told me that my comedy made him homesick. So I like to think my work heals and helps, and provides an alternative, something like Motorcycles and Sweetgrass, as compared to a lot of these really sad novels out there. I think it provides an option, and the fact that we have a wonderfully developed sense of humor. That is why I wrote a book exploring and deconstructing Native humor called Me Funny. The celebration of the Indigenous sense of humor has been something very close to my heart.

RC: But you have also written some plays such as Someday and In a World Created by a Drunken God which present a more serious and darker perspective. Could you comment on that and in what sense these plays can be connected to the idea of theater as a healing performative process?

DHT: It is interesting, when Someday was produced in Montreal, they called it a "Christmas comedy". I tell people I write four types of plays: theatre for young audiences, dramas that have a lot of comedy, comedies in which there is a celebration of the Indigenous sense of humor, and I write what I refer to as intellectual satires, which are plays that are funny but have a darker center to the play and have a unique intellectual perspective. For that I consider AlterNatives, Dead White Writer on the Floor.

RC: So you would say that Someday and In a World Created by a Drunken God are dramas with comedy?

DHT: Yes, I would say that definitely. I know what you are saying about In a World Created by a Drunken God. It is more of a drama, but it does have a lot of humor in it, because I find it practically impossible to write anything without humor. Even my play about residential schools, which was very dark, still had a lot of humor, because, in my opinion, it is part of the Indigenous journey. One time I was at an elders' gathering, I was at the audience, and the elder said "I think we should end this gathering with a smile, so could you please, Drew Hayden Taylor, come up and tell a funny story?" I was sitting at the back, I was not expecting it, then I got up and told a funny story about my mother's 
funeral, and everybody laughed and loved it. I think it was Lee Maracle who said there are two things you need to know about Native people: "we cry and we laugh, and often time, there is barely the width of a paper between the two".

$R C$ : You've written science fiction and other texts in so many different genres. Are there other non-Native writers who have influenced your work?

DHT: I grew up reading mainstream writers all the time, and it was not until my 20s and 30 s that I began to read a lot of Native literature. So I read a lot of classic science fiction, Stephen King, all these different things growing up, and they influenced me. Stephen King, who really does need an editor, sometimes his stuff is way too long, is brilliant at telling a story and characterization, so I really appreciate what he does, even though it takes forever to get to what he is trying to say. I think Kurt Vonnegut Jr. is a better short story writer than he is a novelist. I was up for an interview for CBC to host a CBC show and just because I was asked to comment on a show about Native issues and I was on this show I was being interviewed, and I guess all my references were to Native issues, and one of the producers said, very tactfully: "Do you have any interests outside the Native community?". And I didn't realize I painted myself into a corner and I didn't end up getting the job. But yes, I told you my dream someday to write a Star Trek episode, there is so much out there I would love to do, go out there to explore the world. I'm very proud of my Native storytelling tradition, but I know that is one room in imagined possible experiences.

$R C$ : So you have been working for $C B C$ (Canadian Broadcast Corporation) for some time...

DHT: Right now I am in the process of writing five scripts for CBC for a television series. I have developed and given them, and they've expressed an interest in them, but they will see the five scripts before they give the series the green light.

RC: And you also have a new play that was performing in Toronto?

DHT: In the last year I had two new plays. One of them was here in Ottawa at the National Arts Center. I was asked to write a play about Sir John A. MacDonald from the Canadian perspective and it was a huge success. It was called Sir John A: Acts of a Gentrified 
Ojibway Rebellion, and we are trying to see right now if we get a national tour of it up and running. The other play I did that came in February was a play about what I refer to as the "wild rice wars" in the Kawartha Lakes where my reserve is, where a gentleman from my reserve is planting wild rice in all the lakes and the all the local cottagers don't like it and they are trying to ban it and him. It is called Cottagers and Indians, a play on the term "Cowboys and Indians", so these are my two newest plays.

\section{$R C:$ Would you like to see Brazilian productions of your plays?}

DHT: Every once in a while some of my plays are produced somewhere. I had my play Someday translated into Arabic in Lebanon, because they felt that treatment of Palestinians in Israel was similar to the treatment of Indigenous people by the Canadian government. My play was also taught and I did a couple of scenes at a university in Chennai, India, in what is called the Dalit university, for those called "the untouchables", because they thought the treatment of the untouchables mirrored the treatment of Indigenous people in Canada. So Someday seems to mirror the treatment of a lot of Indigenous or minority people in various cultures, and I sometimes wonder if it translates to other cultures.

$R C$ : I think it is a very important moment to talk about Someday for a Brazilian audience or to produce it from a Brazilian background, since Canada's "scoop-up" of the 1950s and 1960s is happening in Brazil right now, as we see in Tatiane Klein's report to The Intercept. Could you talk about what happened in Canada and the consequences for Indigenous people?

DHT: They call this period the "60's scoop up" when the Children's Aid Society would frequently take away Native children from their families and farm them out for adoptions to non-Native people, primarily white people, because there was frequently a misunderstanding of the child rearing procedure in Native communities. So there are tens of thousands of Native kids raised by white families that are now trying to find their way back or trying to deal with this, and this is one example of misunderstanding. The Western European culture, the dominant culture, has this concept of the nuclear family, the parents, children, maybe a grandparent or two in the house, whereas in the Native community, it was communal existence, where frequently the children were raised by 
the community and it would not be uncommon for a child to spend time in an aunt's, an uncle's, a grandparent's, or a completely different house, which the dominant culture often felt it was a form of child abandonment and would take the children away and say they were not looked after. As I said, it was done by the Children's Aid Society. In Saskatchewan, there was a publicity program put on by the Saskatchewan government urging non-Native people to adopt Native kids, the big irony being the program was called AIM - Adopt Indian Metis, and AIM was the political movement in the States American Indian Movement, and so there is this weird sort of dichotomy.

\section{RC: Could you talk a little about Someday?}

DHT: At that time I was dating a woman who was adopted, and then every once in a while I met somebody in the Native community who was adopted. I began to notice I was having more and more contact with adopted Native people than with adopted non-Native people. It puzzled me, because in terms of ratio, since there are more non-Native people than Native people, you think you will bump more into adopted non-Native people, but it was always Native people. I asked about this and I found out about the scoop up, which I did not know about, and I thought: "Why don't I know this? Other people should know this!", and then I decided to write a play about it. The thing is, about journalism, as they say, "a thousand people killed in a landslide is not a story, it is statistics. One person with a name, a face and a family killed in a landslide, that is a story", so I decided to write a story about a family. In Someday, if you pay attention, it actually does not mention the scoop up, not technically, because that was irrelevant. The name was irrelevant, what happened was important. So I dealt with all that and also part of that was my own personal journey because when I started writing in my late twenties I dealt with identity. What was like, first of all, growing up in a First Nations community the way I look, being fair haired and fair skinned, and I found new ways of exploring it. Once I had talked about myself in my essays Pretty like a white boy and Funny, you don't look like one, I can only explore that way so long, then with something like this, I found a new way of exploring Indigenous identity through adoption. So you have Janice coming back wanting to find out more about her Aboriginal origin, and then there is the sequel, Only drunks and children tell the 
truth, and in that sequel, $400 \mathrm{~km}$. It is also my way of doing a little personal exploration through deconstruction of identity.

RC: Thank you, Drew. I hope someday we can have your visit to Brazil and productions of your plays there.

DHT: That would be lovely.

\section{References}

DRISKILL, Qwo-Li. Theatre as Suture: Grassroots Performance, Decolonization and Healing. In: Hulan, Renée; Eigenbrod, Renate (Ed.) Aboriginal Oral Traditions: Theory, Practice, Ethics. Winnipeg: Fernwood, 2008.

HIGHWAY, Tomson. Dry lips oughta move to Kapuskasing. Calgary: Fifth House, 1989. . The rez sisters. Calgary: Fifth House, 1988.

KLEIN, Tatiane. 'Esquece do seu filho': o Brasil está tirando crianças indígenas de suas mães e colocando para adoção. The Intercept. July 28, 2018.

MARACLE, Lee. Oratory on Oratory. In: Smaro Kamboureli and Roy Miki (Ed.). Trans. Can.Lit: resituating the study of Canadian Literature. Waterloo: Wilfrid Laurier, 2007.

MILLER, Arthur. Death of a salesman. New York: Penguin, 1976.

SHAPESPEARE, William. Hamlet. New York: Dover, 1992.

. King Lear. New York: Dover, 1994.

. Macbeth. New York: Dover, 1993.

TAYLOR, Drew Hayden Taylor. Alive and Well: Native Theatre in Canada. Journal of Canadian Studies, n. 3, v. 31, 29-38, 1996.

. AlterNatives. Vancouver: Talon books, 2000.

. Dead white writer on the floor. Vancouver: Talon books, 2011. . 400 kilometres. Vancouver: Talon books, 2005.

. Funny, you don't look like one: observations of a blue-eyed Ojibway. Penticton: Theytus Books, 1996.

. In a world created by a drunken God. Vancouver: Talon books, 2006. . Motorcycles and sweetgrass. Toronto: Knopf Canada, 2010. . Only drunks and children tell the truth. Vancouver: Talon books, 1998. . Someday. Markham: Fifth House, 1993. . The night wanderer. Toronto: Anick Press, 2007. 


\section{Notas}

1 Associate Professor at FURG, Rio Grande, RS, Brazil. rubelisecunha@furg.br

2 Native Earth Performing Arts - Canada's premiere Native theatre company.

${ }^{3}$ WD-40 is a multi use cleaning product promoted as "the can with thousands of uses. 